\title{
The Power of International Institutions: An Examination of U.S. Policy towards East Timor and Kosovo in 1999
}

\author{
Christopher R. Cook \\ Assistant Professor, Political Science Program \\ Penn State Erie, The Behrend College \\ 5091 Station Road Erie, PA 16563 \\ Tel: 814-898-6071Ｅ-mail: crc17@psu.edu
}

\begin{abstract}
This article looks at American foreign policy towards Kosovo and East Timor in 1999 using the extant literature, internal Administration documents, as well as elite interviews. I then test these cases against a structured focused comparison of two competing hypotheses. The first is realism. Secondly, I develop a hypothesis of institutional agenda setting, based on constructivism and neo-liberal institutionalism. I contend that the best explanation for both cases lies in the second hypothesis. Institutional identity shapes state preferences, not only in decisions to intervene but in shaping the size and scope of the mission. Institutions matter in complex human emergencies.
\end{abstract}

Keywords: East Timor, Kosovo, American Foreign Policy, International Institutions, Humanitarian intervention

\section{Introduction}

In March of 1999 the Clinton Administration used military force to stop a possible genocide of the Kosovar Albanians. Clinton's actions were seen as a fulfillment of his 'Clinton Doctrine' where he called on Americans to think about the security consequences of letting humanitarian conflicts fester and spread. He argued that where "our values and our interests are at stake, and where we can make a difference, we must be prepared to do so" (Klare, 1999). In an ironic coincidence another comparable humanitarian tragedy occurred in East Timor during the same year. Yet, the U.S. did not commit to military action. The cases of Kosovo and East Timor are illustrations of one of the most perplexing puzzles in international relations-- trying to explain why some states intervene militarily in some humanitarian crises but choose other options in other cases. Kosovo received unqualified military support, even though the province was legitimately part of Yugoslavia. Yet in East Timor, President Clinton was content to tell the people of East Timor that they were going to receive limited American logistical support (White House, 1999). There would be no American military to stop the terror of pro-Indonesian militias in a province that had a stronger claim to independence than Kosovo.

One could argue that American foreign policy in East Timor and Kosovo cannot be compared. Was this a simple case of realism: Indonesia is an integral ally of the United States and Yugoslavia is not? For Kosovo, the Clinton Administration was willing to use force without the United Nations (U.N.) because it had the backing of its European allies and the stakes were low. President Milosevic was clearly isolated on the world stage. Whereas military intervention in East Timor would be counterproductive in terms of its immediate and long term impact to U.S. relations with Jakarta, the ASEAN community, and the wider Muslim world. The US could not bomb its way to Dili as they prepared to do in Kosovo. So how can we compare these two crises if we can a priori rule out military intervention in Indonesia?

The ability to find two perfectly matched case studies in international relations is difficult. However, in 1999 Kosovo and East Timor represented growing complex human emergencies with potential for massive human rights violations (some would say genocidal implications) and refugee flows that could swamp neighboring nations. The comparison is not between Yugoslavia and Indonesia - but the American response to the dangers faced by the Kosovar Albanians and East Timorese people. Furthermore, a comparison of both highlights what is often missing in the literature humanitarian intervention there are levels or degrees of intervention. When the U.S. provides the financial and logistical support to other organizations (like the U.N.) and nations in humanitarian crises-- but does not send "boots on the ground" it is still an intervention of sorts. In fact, a large component of U.S. participation in U.N. peacekeeping is not providing military but critical logistical aid. This then begs the question of why the literature is often missing the role international institutions play in helping formulate logistical limited interventions. (Note 1)

This article is an examination of U.S. policy towards both conflicts in 1999. I try to answer the question of how international institutions shape the level of American response to each conflict. They can help us understand the decision to logistically support the International Force for East Timor (INTERFET) or NATO's use of air strikes in 
Kosovo. To answer these questions I will carefully look at the extant literature, internal memos from the National Security Council (NSC), Defense and State Departments combined with my own and other elite interviews of key Clinton decision makers. I will then test them against a structured focused comparison of two competing hypotheses of foreign policy. The first hypothesis I have chosen is realism, still considered the dominant paradigm of foreign policy scholarship. Secondly, I develop a hypothesis of institutional agenda setting, based on constructivism and neo-liberal institutionalism (Cook, 2008). These hypotheses will hopefully shed theoretical light on how the Administration framed American policy in both cases and how it understood the possible policy options to end the suffering.

\section{Competing Theories of Foreign Policy and Testable Hypotheses}

Realism is often seen as the dominant paradigm of global relations; but it does not have much to say about humanitarian intervention and even less about peace operations. Foreign policy, to realists is about the promotion and protection of the national interest as defined by the distribution of power in the world. Intervention in strictly humanitarian crises-- is by definition outside national security (Grieco, 1988). Interventions are rooted in self interest. Furthermore, membership in an international institution cannot subsume the individual interests of its members. Thus, I argue that one should find that at the core of every peacekeeping operation is an internal sober analysis of national interest (Rose, 1998). Policymakers must perceive that something will be gained from participating in these kinds of international ventures. A successful mission might maintain or change the distribution of power but always to the benefit of the intervening nation (Schweller, 1998).

The starting point for any discussion of U.S. policy in East Timor should begin in 1975. At the time American policy in East Asia was driven by a simple and powerful goal-- the containment of communism. As one of the most populated nations in the world, and strategically placed in the shipping lanes Indonesia was seen as the crucial linchpin to this policy. Richard Nixon called the country "the greatest prize in the Southeast Asian area" (Pinto and Jardine, 1997). Thus the U.S. looked the other way when Indonesia invaded and annexed East Timor. Some estimates claim that over the next several years the Indonesians directly or indirectly killed 100.000 or a third of the Timorese population (Taylor, 1999). The U.S. continued to ship weapons and train Indonesian officers. In essence, the people of East Timor were sacrificed for geo-political realities of the Cold War.

In many ways Kosovo could not have been any more different than East Timor. For one, Kosovo was always considered an integral part of Serbia. However, during the Ottoman Empire Kosovo had become predominantly Albanian (Glenny, 2001). In 1974 the Kosovar Albanians were given a measure of cultural and political autonomy. But after Tito's death the Serb Parliament ended this deal and President Slobodan Milosevic, stepped up their official harassment. The Kosovar Albanian population, now under attack demanded independence (Mertus, 1999). Initially this movement took the form of a non-violence movement. But as Serb aggression continued a new group emerged calling themselves the Kosovo Liberation Army (KLA) believed that independence could only be achieved with violence and terrorism.

What kind of hypothesis could we derive with a realist theory when it comes to understanding Kosovo and East Timor? Simply put Washington will privilege stability over self determination and human rights. If this hypothesis is true we will find the Clinton Administration making choices to intervene or not based on explicit arguments of American national interests. These findings will be strengthened if we find evidence that top Clinton decision makers made consistent and repeated references to the geo-strategic and financial stakes in their comments to the media, minutes from official meetings, memoirs, government papers, reports, and personal interviews.

\subsection{The Institutional Norms and Humanitarian Intervention}

International organizations become the center for understanding interventions because they are the transmission belt between the competing norms of humanitarian intervention on one hand and sovereignty and national interest on the other (Cook, 2009). Martha Finnemore is correct to say that modern norms of intervention seem to trump sovereignty in military interventions (2003). But the ideas of sovereignty and non-intervention are just as entrenched at the international level as stopping gross human rights abuses. Institutions are not black boxes. U.N. identity is not a fixed concept but a dynamic interaction. International organizations are a battleground of competing norms, practices, and rules. The Security Council is simultaneously a collective actor, and a forum in which member states pursue rational interests. States bring to the UN different interests and are thus pushing back on institutional norms. They are quite capable of picking which norms to champion and which to rearrange into new patterns of politics" (Duffield, 2007, p. 9). So for example, when it comes to humanitarian interventions there are plenty of examples of American inaction in the face of tragedy.

However, while I am arguing that humanitarian intervention is growing in legitimacy it is not an automatic outcome of policy. A norm of humanitarian intervention does not reveal exactly what kind of intervention will take 
place. All institutions can do is transmit an idea that multilateral action is the best way to end gross human rights abuses even in the face of institutional weakness and the possibility of sub-optimal policies. Institutions may not be able to overcome national interests but states can do more than just exit a peacekeeping mission-- they can influence the size, scope and breadth of the mission itself (Finnemore and Sikkink, 1998).

Our second hypothesis provides us a framework to examine humanitarian policy in East Timor and Kosovo. This hypothesis suggests that international institutions will help shape and mold an American policy outcome in these crises. Furthermore, the findings will be strengthened if we see evidence that top decision-makers were explicitly concerned about participating in international organizations from their comments to the media, minutes from official meetings, memoirs, government papers, reports, and personal interviews.

\section{American Decision Making in Kosovo}

When violence in the Kosovo province started to escalate after the 1995 Dayton Accords, the west pressed Milosevic to negotiate directly with the Kosovar people (Dempsey, 1998). But the international community sent Yugoslavia mixed messages: on one hand they requested that the Serbs give the Albanians more autonomy, to treat them fairly, and protect their human rights. But on the other hand, the world wanted to protect Yugoslav territorial integrity. An independent or partitioned Kosovo could set a dangerous precedent for the partitioning of Bosnia. This mixed messages only fueled the Milosevic regime to continue its campaign against Kosovo.

By the autumn of 1998 the Serbs had forced roughly 300.000 people from their homes in the province. Washington sent envoy Richard Holbrooke to meet with Milosevic to personally press him to stop attacking civilians, withdraw some of the Yugoslav security forces from the province, and grant access to humanitarian groups (Daadler and O'Hanlon, 2000, p. 24). In their magisterial work on Clinton's policy in Kosovo Ivan Daalder and Michael O'Hanlon point out that the talks stalled because Milosevic was convinced that force would not be used because the U.S. did not have international support (2000). Holbrooke only got a diplomatic agreement by stating that Germany and Italy were all ready on board for NATO air strikes (Harris, 1999). The agreement called for a Kosovo Verification Mission to allow people to return to their homes and install international monitors to verify if Belgrade was complying with U.N. Resolutions (Cohen, 1998, p. A6).

The Holbrooke/Milosevic agreement was riddled with problems. For one, the agreement ignored the KLA and in the words of one American official: "We don't have leverage on the KLA, it is a missing element in our overall strategy" (O'Connor, 1998, p. A3). Secondly, Daalder and O'Hanlon point to the refusal to seriously contemplate using ground troops to monitor any kind of future peace agreement. They cite one White House official, "the idea of troops never had any traction" (2000, p. 53). During November Milosevic approved "Operation Horseshoe," a plan that would nullify the Verification Mission and solve the "Kosovo problem" by emptying the Albanian villages. He reasoned the west did not have the resolve to use force (Smith, 1998, p. A16). He waited for an inevitable KLA attack as an excuse to launch his plan. The Clinton administration had not anticipated the Holbrooke agreement to break down so quickly and there was no plan 'B' available (Daadler and O'Hanlon, 2000, p. 62).

Secretary of State Albright pushed for air strikes against Serbia. That was the lesson she took from the Bosnian conflict-- the Serbs would crumble under sustained bombing. She pressed for action at a N.S.C. principals meeting on January 15, 1999. Albright told them they had three choices for Kosovo: Stepping back, muddling through or taking decisive steps" (Perlez, 1999, p. A8). Albright was clear that Milosevic only understood force. But if we look at the policy up to this point-- humanitarian intervention was tempered by a realization that an international consensus was needed if Milosevic was going to believe American threats. Official US policy at the beginning of January 1999 can be summed up as: "promote regional stability; protect the investment in the Bosnian peace process; and prevent the resumption of hostilities in Kosovo and stop a renewed humanitarian crisis; combined with preserving U.S. and NATO credibility" (Sciolino and Bronner, 1999, p. 13). International consensus and institutional credibility becomes intertwined with humanitarianism.

Albright proposed an international protectorate of Kosovo even if that meant using ground troops. She proposed one final round of negotiations with all sides of the conflict. The new negotiations would be modeled on Dayton with the threat of force if the talks failed. The allies were hesitant to act but Albright had some success. At a North Atlantic Council Meeting; Secretary General Solana promised: "NATO does not rule out any possibility. Therefore every possible option is open as it is stated" (NATO Statement, 1999). The U.N. Secretary General in a symbolic move endorsed the new NATO policy in his meetings with the Security Council. (United Nations, 1999) Albright concluded there "should be no doubt on either side that the consequences of failure to reach agreement or to show restraint on the ground will be swift and severe" (U.S. Department of State, February 4, 1999). But Milosevic was not as sure as he watched domestic politics in Washington and the trepidation in European capitals 
towards the use of combat troops. Unlike in East Timor Albright put the entire weight of NATO legitimacy and by definition the U.S. on the line-- even when Washington and its allies did not truly want to use every possible option. Albright institutionalized Kosovo policy through NATO.

The disputing Kosovo parties met at an old French chalet named Rambouillet on February 6, 1999. The French and British chaired the meeting and three negotiators represented the U.S., the E.U. and Russia. They met with the ethnic Albanian team consisting of the KLA and Rugova factions and Serbian representatives (Milosevic refused to attend).The starting point was a US document revolved around the following points: 1) democratically accountable and representative institutions in Kosovo; 2) The protections of human rights; and building a dispute resolution mechanism; 3) the territorial integrity of Yugoslavia; 4) end of all violence; and 4) international involvement in the agreement implementation.

The fact that Milosevic did not personally show up was not a good sign of things to come (Daadler and O'Hanlon, 2000, p. 79). The Kosovar delegation had a deep rift between the KLA and Rugova factions. On the allied side the disagreements were just as sharp. As in Dayton the allies were preparing an international peacekeeping force to implement when the peace deal was completed. The working name of the mission was Kosovo Force (KFOR). Most of the Europeans, led by the French, wanted the mission to work through the U.N. The United States refused. They cited the difficulties of obtaining the consent of the Chinese and the Russians through the Security Council. The United States won this diplomatic fight at Rambouillet and the mission was to be exclusively run through NATO. However, this is important to note that NATO not the Security Council had a veto on any proposed mission.

As the negotiations wore on they stumbled on several procedural roadblocks. For one Milosevic refused to have any foreign troops on Yugoslavian soil (Perlez, 1998, p. A8). The deadline to have the treaty finished came and went and both groups refused to sign. Albright wanted to get the Kosovar Albanians to sign and put the blame on the Serbs for letting the agreement fail. She personally visited the Albanian delegation to get them to sign and was at first rebuffed. Albright leveled with the delegation leader: The US could easily turn around and let the Serbs do what they wanted. The Kosovar delegation arrived in Paris two weeks later to sign the accord (Halberstam, 2001). The Serbs ignored the potential threats and started moving troops back into the Kosovo province. They did not believe that NATO was serious. Sandy Berger stated: "Milosevic was playing a game with us at Rambouillet by building up his force while pretending to negotiate seriously, so were we. We needed to demonstrate real commitment to get a peaceful resolution in order to get the allies to go along with the use of significant force" (Daadler and O'Hanlon, 2000, p. 89). For Washington showing commitment to our NATO allies was almost as important as protecting the Kosovar people. Six days later the bombing started.

Why intervention? Realism provides a partial explanation of American policy. The evidence suggests that underneath a veneer of human rights there remained an overriding sense of maintaining regional stability and protecting American and NATO credibility. American officials feared Kosovo would bleed into Bosnia where 20,000 American troops were already stationed and into the Former Yugoslav Republic of Macedonia. Misha Glenny points out that Serbia was served by a weak Macedonia. The Turks were also weary of Macedonia, for the welfare of Muslims and for regional stability as a whole. Secondly, Albright pegged the success of Rambouillet Conference to the prestige of NATO and American force. Between the threats of force and importance of the region the U.S. acted. Glenny notes, "American policy in the region is not borne of altruism but clear understanding of American interests" (Glenny, 1995).

National interests can be served through intimidation, threats and skillful manipulation. However, one methodological flaw with realism is how to measure or rank order national interests and matches it with the various tools in a realist tool chest. Not all vital interests are the same: Which interest deserves air strikes and which can be solved with sanctions? This is an important concept if one wants to predict possible policy outcomes. If you posit that regional stability were of primary strategic value then every option (including the need for the use of ground troops) should have been on the table. This was not the case. The U.S. only used air strikes in Kosovo because they knew they had the backing of its European Allies. But why would the Administration bother putting NATO prestige on the line? However, it is here that we find an opening for our second hypothesis.

The international commitment hypothesis allows us to look deeper into the choice of using NATO as the primary instrument of policy. Inside the trans-Atlantic alliance are strong norms for reaching consensus. At each critical phase Milosevic judged American rhetoric with the willingness of the European allies to back it up. His eventual capitulation was the realization that the Europeans were rallying behind the proposal of a ground invasion. But membership in NATO created constraints on Washington. The Administration may have dragged the Europeans along but they had plenty of input on policy. In essence the Europeans pushed back within the institution and 
modified the planning. The US listened and communicated with its NATO allies even though unilateral action would have been a simpler solution. Secretary of Defense William Cohen argued: "if we were to carry out and act unilaterally, [in Kosovo] we would have much more robust, aggressive, and decapitating type of campaign... The difference here, of course, is that we're acting as an alliance" (Graham, 1999, p. A24).

Yet, for the importance of realist rhetoric about regional stability it is interesting to note that Clinton and Albright chose a sub-optimal NATO policy that Washington could not directly control. This is why our second hypothesis can help predict the policy that was actually chosen. The collective institutional decision making (and the mediation of norms) of NATO becomes as equally important as the human rights of the Kosovar people. The organization becomes the determinant of policy not vital interests. How is the use of air strikes to protect the stability of the region pragmatic when there was no discussion of what would happen if Belgrade refused to capitulate? In a June 2, 1999 meeting Sandy Berger met with a prominent group of outside foreign policy experts about the status of the Kosovo campaign. Berger stated, "failure to win... would do serious harm to the US, NATO, and European Stability." He also stated that we will win with or without NATO. "NATO is so important that we would go it alone just to protect the outcome" (Erlanger, 1999, p. 6). This may be an example of hyperbole. One could speculate that Berger was choosing his words carefully to sell the Kosovo campaign to a skeptical audience. But Berger's statement about the role NATO played in planning the intervention and limiting options is backed up in the literature, internal documents and interviews.

Intervention is a spectrum. I argue that the choices of where a nation falls on this spectrum are partially shaped by international institutions. Washington made a decision to institutionalize Kosovo policy through NATO-- an institution they value as the bedrock to security in Europe. That was the outcome of the Rambouillet Conference: The protection of the Kosovar Albanians was yoked to the credibility of NATO and the institutional commitment that it entails. The United States did not have to choose NATO as the appropriate vehicle. When it comes to humanitarian crises Washington could have always chosen to do nothing as well. The final policy chosen in Washington was shaped - not necessarily out of realist concerns for the region but the need for consensus in European capitals.

\section{American Policy toward East Timor}

At the same time as events were unfolding in Kosovo another humanitarian crisis was starting to heat up on the other side of the world. Yet, the United States treated this incident quite differently. Major decisions were left to the U.N., or other countries like Australia. The matter was primarily vetted through the NSC Deputies Committee and did not enjoy the same kind of personal attention from the Cabinet as Kosovo. But that is not to say the U.S. did nothing, as I mentioned earlier there is an intervention spectrum: Americans gave logistical and financial support for the Timorese referendum on independence. But is this a case of realism? In this section I hope to map out the impact the United Nations had on the formation of American policy. (Note 2)

With the resignation of President Suharto Indonesian politics started to shift. The domestic turmoil had a positive impact on the contested status of East Timor. Indonesia was willing to talk in the wake of the financial crisis. They agreed to UN mediated talks in 1998. Jakarta offered to rescind its territorial claim if an offer of special autonomy within Indonesia was rejected by a vote of the Timorese people. The details of that consultation vote were worked out in a May 5, 1999 agreement between the UN, Indonesia and the former colonial power Portugal. The U.N. Mission in East Timor (UNAMET) was established in Resolution 1246 (1999) to hopefully conduct this referendum in June. The agreement made Indonesia responsible for maintaining peace and security and free of intimidation, and violence. The agreement also called for an orderly transfer of authority in East Timor to the authority of the UN if the vote was for independence. But as with Kosovo Verification Mission there was no enforcement mechanism.

The State Department noted that Portugal was willing to put up a sizable sum of money to finance the referendum but the UN would need support from its larger member states. The Clinton Administration wanted to help but the overriding concern was defining the costs and personnel needed. As one official noted, U.S. policy was to avoid owning the issue. Washington ended up working informally behind the scenes to forge a viable resolution (U.S. Department of State, April 1, 1999). However, they made a subtle and important change in American policy towards Indonesia within the U.N. Instead of allowing Indonesian stability to exclusively dictate a "don't ask don't tell" policy towards human rights American policymakers used the institution of the UN to expand the Indonesian debate. (Schwartz, One N.S.C. official stated, "We supported an open debate in the Security Council which was attended by over 50 representatives from nations across the globe -- all of whom criticized the Indonesians." Habibie realized he was isolated and agreed to the consultation vote. The US found a way to support Timor, "while showing [Indonesia] it was the best course of action through the UN" (N. Soderberg, Interview by author, telephone, July 15, 2002). 
The Administration was also cognizant that the situation inside East Timor was going to deteriorate. There was an increase of intimidation from pro-Indonesian militias. The US tried to convince Jakarta to restore security and calm before the vote. A U.S. Department of State, Discussion Paper for NSC Peacekeeping Core Group noted the opposition the Indonesians had to letting Timor peacefully go. Humanitarian organizations were hindered from providing needed medical assistance due to security concerns. (April 19, 1999) The State Department and Deputies Committee prepared an in depth analysis (PDD-25) of East Timor policy in preparation for the UN vote to establish the referendum mission (UNAMET) (May 7, 1999). According to the Department of Defense the two major sticking issues facing the UN mission were a need for a clearer mandate. Was this going to be a Chapter VI or Chapter VII enforcement? (May 21, 1999) Secondly, there was no substantial exit strategy considering the uncertainty of how the vote would turn out. A Defense Department Memo on May 26 noted that if there was an increase of violence the UN resolution was probably the wrong mandate.

However, with these flaws in mind the Deputies still decided to officially vote for the establishment of UNAMET. Policymakers understood that the resolution had clear shortfalls but "the consequences of inaction to regional stability were weighed and considered unacceptable"(Department of State, May 20, 1999). The PDD-25 stressed the unique nature of Timor since this was not an international conflict but an internal one. [This technically may be wrong.] Washington also worried that Jakarta was in fact aiding and abetting the militia in an attempt to ensure the consultation would produce a vote for autonomy. There was growing evidence that Indonesian security forces often stood by, or in some cases, actively participated in attacks on pro-independence and UNAMET offices (Human Rights Watch, 1999).

By July the UN Secretary General reported that while UNAMET was fully deployed violence continued to interfere with preparations for the popular consultation. In response the UN Secretary General delayed the consultation vote. But the intimidation campaign failed. The UNAMET-led registration period that opened July 16 and ended August 6 exceeded expectations. Madeline Albright could boast that: "Already, more than 400.000 East Timorese have registered to vote, showing tremendous courage under difficult, emotionally-charged circumstances... Security concerns will not end when the votes are counted" (U.S. Department of State, August 12, 1999). While that was the public face the Intelligence community informed the White House that mass violence would probably break out if Timor voted for independence (U.S. Department of State, August 30, 1999). But there was no serious discussion that the U.S. would use its own troops.

On August 30, 1999 the consultation vote was held. Even though the vote seemed to go off without a hitch East Timor remained explosive. The NSC Deputies Committee met the next day to discuss further US diplomatic actions to influence the Indonesian government and military to control the inevitable militia violence when the results were announced. The Deputies also considered a range of other options including trying to get a larger multinational force (from a reluctant international community) and expanding U.N. operations in East Timor (White House, 1999).

The results were released on September 3 and independence was chosen by $78.5 \%$ of the population. The militias began their organized wave of terror, including reports of death lists being used. As one US diplomat put it: "There was kind of a hope and a prayer approach [to Timor] that the U.N. would monitor and hopefully that would be enough to dissuade the Indonesians from violence, of course it was not enough and then we had to react quickly once that became a front page crisis" (Confidential Interview with Author). The reaction from Washington to the growing East Timor crisis was quick, but tempered by several factors: First, was the realization that the only way to control the spreading violence was to send in U.N. backed peacekeepers not the police and poll watchers already there. Second, Washington realized that the only way peacekeepers could arrive was with the consent of Indonesia whose role in the violence was questionable. This is important to note because the norms of humanitarian intervention exist alongside the norms of protecting sovereignty. Third, the U.S. was not going to send a peacekeeping force. Troops would have to come from somewhere else. One NSC official stated, "I can remember the Deputies meeting where [James Steinberg, Deputy National Security Advisor] expressed grave concerns about the risks involved. There were alternatives in East Timor but there were not good alternatives" (Confidential Interview with Author). One State Department official stated,

"Once violence starts it has the characteristic of going in its own direction. We contemplated a variety of scenarios... In East Timor, you were never sure just what was going to happen. I think had that vote not been $79 \%$ for independence, if it was 53\%-54\% there would not have been any multi-national force. One of the scenarios discussed had the Indonesian military staying and fighting and then you are talking about a multi-national force that is no less than 20-30,000. That is why the political legitimacy of the referendum was crucial to the intervention" (Leonard Hawley, interview by author, tape recording, May 28, 2002). The legitimacy of the referendum helped start to ameliorate the concerns towards sovereignty. 
A U.N. aide reported: "If Indonesia accepts the help of foreign forces the matter will probably be handled very quickly" by the Security Council. "That's what we're all waiting for -- the green light" (Aita, 1999). U.S. Ambassador to the U.N. Richard Holbrooke made clear that the Security Council would not authorize the intervention of foreign forces in East Timor without the express consent of the Indonesian government (Aita, 1999). On September 12 President Habibie signaled that Indonesia would accept peacekeepers. Behind the scene U.S. diplomatic pressure proved critical in securing approval of the mission. "American support, diplomatic support, was very important," Australian Prime Minister John Howard stated. "The Americans put a lot of diplomatic pressure on Jakarta" to agree to an international force (Kelly, 2009). But Washington's diplomatic role was couched in the terms of membership in the United Nations not as its role of regional power player.

It would be untrue to say that the U.S. did not help the people of East Timor. Washington not only helped diplomatically, but they provided logistical aid to the Australian led international force of peacekeepers (INTERFET). On the first of November the last Indonesian Army units left East Timor. Most of the militia fled to West Timor with them. We have noted that realism privileges Indonesian stability as the fulcrum to East Asian security not the people of East Timor. INTERFET served the geopolitical, economic and security interests in the region by preserving Washington's relations with Indonesia. In fact, some might argue that the United States allowed the U.N. to dominate the East Timor agenda as part of a skillful diplomatic move-- that effectively internationalized the conflict and allowed for an external intervention. The stability of this Muslim nation, with the fourth largest population of the world sitting on top of a host of natural resources is still an American strategic interest. The United States was in no position to alienate the Indonesians (White House, July 16, 1999). However, it is important to point out that realism is not defined as the pragmatism of elite policy makers.

Thus realism can generate alternative scenarios. Eric Schwartz argues that "Indonesian intransigence on the issue could lead to international isolation and in conjunction with the collapse of the Indonesian economy, threaten its transition to democracy" (2001). But does this explanation alone satisfy our realist hypothesis? Critics of the Administration argued that the United States could afford to let East Timor remain part of Indonesia. East Timorese independence would add legitimacy to other secessionist movements like West Papua and Aceh. Leon T. Hadar argued that such a situation was a "slippery slope" and that Washington would have to become the "stabilizer of last resort" in the region (1999). In hindsight the perceptions of the Administration but in the spring and summer of 1999 the future of Indonesia, sans U.S. participation in UNAMET and INTERFET is indeterminate. Realism is not ruled out as an explanation because it can provide an explanation for whatever choice Washington makes. Does East Timor change the power balance of East Asia? There is a difference of opinion. The argument that the U.S. used the U.N. to achieve its realist policy objectives suffers because a simpler more parsimonious answer would have the United States (if it truly did dominate the U.N. agenda) nix the U.N. plans for a referendum and have the Portuguese and Indonesians go back to the negotiating table to haggle. Why bother supporting the referendum at all?

A possibly stronger explanation for U.S. policy, that can both address why Washington became involved; and secondly predict the level of intervention lies in the power of norms and the international commitments to global institutions. When it comes to a strict analysis of the "Clinton Doctrine" East Timor fails to meet the American bar for national interest. However, there was still a discussion of norms: human rights, self determination and being a member of a global institution and how they interact with the norms of sovereignty. How did East Timor end up on the American agenda in the first place? When East Timor was placed on the U.N. agenda, by the renewed Indonesian and Portuguese talks it became a topic of the N.S.C. because of our institutional commitments. According to internal documents the driving argument inside the White House is how to help implement the referendum first, not concerns of Indonesian security which came second. Secondly, how should the United States implement the referendum? Obviously they were not going bomb there way to Dili if a vote for independence failed. There was no international will in the U.N. to militarily force the Indonesians to do anything. We come back to the spectrum of intervention and the importance of institutional decision making. The U.S. would choose a "limited role" in the conflict. But the evidence is clear there was never going to be American boots directly on the ground.

\section{Theoretical Implications and Conclusions}

Ten years later Timor-Leste and Kosovo are independent nations. The humanitarian missions that set them on the path to independence can be considered successes. By using Kosovo and East Timor as case studies of American policy towards complex human emergencies this article attempted to understand and highlight the institutional aspects of the theoretical debate on intervention. Scholars have often looked at humanitarian intervention as a simple dichotomy: you either intervene or you do not. But that is an over simplification. The U.S. did do something in East Timor (whether it was enough is a qualitative judgment). Through the use of primary documents, key 
interviews and the extant literature we have been able to map out an understanding of how institutions shaped the way Washington understood the possible policy options in front of them.

Realism remains the dominant paradigm of international relations. But the theory is more than just a post hoc understanding of rational decision making. To a realist theorist a threat to regional stability demands the U.S. do something-- but what? The range of possibilities is endless including everything from sanctions to military action. To answer these questions require an understanding of not only the balance of power but a rank ordering of what exactly are American national priorities. However, we are still left with difficult questions about measuring the importance of humanitarian intervention to American goals: If the Kosovo province and Indonesia were so important to the security of their respected regions, then why leave the decision making to the collective wisdom of NATO or better yet the United Nations? We have two scenarios: First, A realist would say that the U.S. used these institutions as a cost saving mechanism to protect their interests. Of course the U.S. would have vetoed any Security Council Resolution that jeopardized its security interests in Indonesia. However, in the hundreds of internal Administration documents analyzed: from the Deputies Committee of the National Security Council to the peacekeeping core groups in State and Defense we do not find any evidence to corroborate that.

Secondly, a realist would argue that this is about regional security: a Serbian pogrom or the mass expulsion of the ethnic Albanian population in Kosovo would have an immediate negative impact on American security considerations throughout the region. The U.S. had already committed 20,000 American troops in neighboring Bosnia and the possibility of unrest widening to Macedonia loomed. Furthermore, the U.S. had already promised the use of force. On the other side of the world a realist discussion of East Timor must include the fact that Indonesia is a pivotal state to American security. Yet, realism can present scenarios for both intervention and non-intervention in both cases. Stability alone does not dictate policy.

This leads us to hypothesis two and the importance of international institutions in humanitarian tragedies. Institutions mediate the effects of competing strategic and material interests of member nations with the norms of human rights. But states are active participants in the feedback process. But one thing is clear the size, scope and breadth of peacekeeping missions are partially reflections of the international consensus. It would be hard to isolate American decision making in Kosovo from the institution of NATO. The use of force was linked to the reputation not just to the U.S. but the European allies as well. The crisis of the Kosovar Albanians had morphed into a defense of the institution. In the case for East Timor we also find the importance of institutions. Some American officials felt that East Timor represented another major test of UN credibility (not American) and its ability to conduct peacekeeping. American participation in creating the UNAMET and UNTAET missions reflected these institutional concerns of credibility. One cannot escape the importance of the norm of "belonging to an international community." Supporting Australia is based on a norm. Without the UN and the Australians, it is doubtful that the US would have intervened in any capacity. The UN placed East Timor on the American agenda not the other way around. The US was dedicated to helping the UN consultation but it was not going to lead. Hypothesis two does a better job explaining American policy.

The Clinton White House is not the first (or last) to argue that where "our values and our interests are at stake, and where we can make a difference, we must be prepared to do so." The war on terrorism has not stopped the debate about humanitarian intervention. Of course I have only two case studies from within the same Administration. In order to truly explore the power of international norms and the power of institutional membership one needs to look at other kinds of interventions across time and locations. However, institutions matter: in how we see and understand conflict and providing us with clues to solve them.

\section{References}

Aita, Judy. (September 7, 1999). UN Mission Will Urge Indonesia to Accept Foreign Peacekeepers on Timor: Holbrooke says U.S. actively seeking solution to East Timor crisis. U.S. Information Agency, Washington File.

Claude Inis L. (Summer 1966). 'Collective Legitimatization as a Political Function of the United Nations' International Organizations, 20:3, 370-2.

Cohen, Roger. (9 October 1998). Americans Rebuke Yugoslav Leader. New York Times, p. A6.

Cook, Christopher R. (2009). A Question of Intervention: American Policymaking in Sierra Leone and the Power of Institutional Agenda Setting. African Studies Quarterly $10 \quad$ (1). Retrieved from http://africa.ufl.edu/asq/v10/v10i1a1.htm.

Cook, Christopher R. (2010). East Timor and the Power of International Commitments in the American Decision Making Process. Asian Pacific: Perspectives 9, no. 2

Daalder Ivo and Michael O’Hanlon. (2001). Winning Ugly. Washington, D.C.: Brookings. 
Dempsey, Gary. (8 October 1998). Washington's Kosovo Policy: Consequences and Contradictions. Policy Analysis p. 17.

Duffield, John. (Spring 2007). What re International Institutions. International Studies Review 9 (1), 1-22.

Erlanger, Steven. (7 November 1999). NATO Was Closer to Ground War in Kosovo Than is Widely Realized. New York Times, p. 6

Finnemore Martha and Kathryn Sikkink, "International Norm Dynamics and Political Change," International Organization 52 (4) 887-917.

Finnemore, Martha. (2003). The Purpose of Intervention: Changing Beliefs about the Use of Force. Ithaca, New York: Cornell.

Glenny, Misha. (2001). The Balkans: Nationalism, War \& the Great Powers, 1804-1999. New York: Penguin.

Glenny, Misha. (May/June 1995). Heading Off War in the Southern Balkans. Foreign Affairs 74 (3)

Graham, Bradley (11 April 1999). Cohen Wrestles with a Mission Far Harder than predicted. Washington Post, p. A24.

Grieco Joseph M. (1988). Anarchy and the Limits of Cooperation: A Realist Critique of the Newest Liberal Institutionalism. International Organization, 42, no. 3, 485-507.

Hadar, Leon T. (December 20, 1999). East Timor and the 'Slippery Slope' Problem," Foreign Policy Briefing (CATO Institute), Retrieved from http://www.cato.org/pubs/fpbriefs/fpb55.pdf

Halberstam, Dave, (2001). War in a Time of Peace: Bush, Clinton, and the Generals. New York: Scribner.

Harris, John F. (1 April 1999). Advice Didn’t Sway Clinton on Air strikes. Washington Post, A1.

Hawley, Leonard. (Interview by author, tape recording, May 28, 2002).

Kelly, Joe. (29 August 2009). “A Tough Job Done in East Timor,” The Australian, Retrieved from http://www.theaustralian.news.com.au/story/0,25197,25994185-28737,00.html

Klare, Michael T. (April 19, 1999). The Clinton Doctrine. The Nation. Retrieved from http://www.thenation.com/doc/19990419/klare.

Mertus, Julie A. (1999). Kosovo: How Myths and Truths Started a War. Los Angeles: University of California Press.

NATO, (January 28, 1999. "Statement to the Press by NATO, Secretary General, Dr. Javier Solana," NATO Press Release 99 (11).

O’Connor, Mike. (4 December 1998). Kosovo Rebels Gain Ground under NATO Threat. New York Times, p. A3 Perlez, Jane. (11 February 1999). Trickiest Divide Are Among Big Powers at Kosovo Talks. New York Times, p. A8.

Perlez, Jane. (18 April 1999). Defiant Yugoslav Orders Expulsion of U.S. Diplomat. New York Times, p. A8.

Pinto, Constâncio and Matthew Jardine (1997). Inside the East Timor Resistance. Toronto: James Lorimar and Company.

Rose, Gideon. (1998). "Neoclassical realism and theories of foreign policy" World Politics 51 (1), 144-172.

Schwartz, Eric. (2001). The Intervention in East Timor. Prepared for the National Intelligence Council Project on Intervention and Internal Conflict, Center for International and Security Studies, University of Maryland School of Public Affairs.

Schwartz, Eric. (Interview by author, tape recording, May 27, 2002)

Schweller.,Randall L. (1998). Deadly Imbalances: Tripolarity and Hitler's Strategy of World Conquest. New York: Columbia University Press.

Sciolino Elaine and Ethan Bronner. (18 April 1999). How a President, Distracted by Scandal, Entered Balkan War. New York Times, p. 13.

Smith, R. Jeffrey. (30 December 1998). Both Sides Resist U.S. Proposal in Kosovo. Washington Post, p. A16.

Soderberg, Nancy. (Interview by author, telephone, July 15, 2002).

Taylor, John G. (1999). East Timor: The Price of Freedom. London: Zed Books. 
United Nations (January 28, 1999). "Secretary General Calls for Unconditional Respect for Human Rights of Kosovo Citizens, in Statement to NATO," United Nations Press Release, SG/SM/6878.

U.S. Department of State, Secretary of State Madeline K. Albright. (February 4, 1999). Remarks at the U.S. Institute of Peace. Washington, D.C.

U.S. Department of State, Info Memo for NSC Peacekeeping Core Group. (April 1, 1999). In documents collected for the General Accounting Office, (September 2001). UN Peacekeeping- Executive Branch Consultation With Congress Did Not Fully Meet Expectations in 1999-2000. GAO-01-917. Washington, D.C.

U.S. Department of State, Discussion Paper for NSC Peacekeeping Core Group, April 19, 1999. In documents collected for the General Accounting Office, (September 2001). UN Peacekeeping- Executive Branch Consultation With Congress Did Not Fully Meet Expectations in 1999-2000. GAO-01-917. Washington, D.C.

U.S. Department of State, PDD-Analysis for NSC Deputies Committee, May 7, 1999. In documents collected for the General Accounting Office, (September 2001). UN Peacekeeping- Executive Branch Consultation With Congress Did Not Fully Meet Expectations in 1999-2000. GAO-01-917. Washington, D.C.

U.S. Department of Defense, Discussion Paper for NSC Peacekeeping Core Group, May 21, 1999. In documents collected for the General Accounting Office, (September 2001). UN Peacekeeping- Executive Branch Consultation With Congress Did Not Fully Meet Expectations in 1999-2000. GAO-01-917. Washington, D.C.

U.S. Department of Defense, Info Memo for NSC Deputies Committee, May 26, 1999. In documents collected for the General Accounting Office, (September 2001). UN Peacekeeping- Executive Branch Consultation With Congress Did Not Fully Meet Expectations in 1999-2000. GAO-01-917. Washington, D.C.

U.S. Department of State, Discussion Paper for NSC Peacekeeping Core Group, May 20, 1999. In documents collected for the General Accounting Office, (September 2001). UN Peacekeeping- Executive Branch Consultation With Congress Did Not Fully Meet Expectations in 1999-2000. GAO-01-917. Washington, D.C.

U.S. Department of State, Info Memo, for NSC Deputies Committee, August 30, 1999. In documents collected for the General Accounting Office, (September 2001). UN Peacekeeping-Executive Branch Consultation With Congress Did Not Fully Meet Expectations in 1999-2000. GAO-01-917. Washington, D.C.

U.S., White House, (July 16, 1999). Office of the Press Secretary, President's Statement on East Timor. Washington D.C.

U.S. White House. (September 16, 1999). Office of the Press Secretary. President's Statement on East Timor. Washington D.C.

Whitney, Craig R. (17 March 1999). Serbs reinforce Kosovo Forces Clouding Talks. New York Times, p. A1.

\section{Notes}

Note 1. There are also plenty of large ' $n$ ' quantitative works on "third party" and UN interventions. However, these studies have the UN as the focus of analysis and not Washington.

Note 2. For a more extensive treatment of American policymaking in East Timor please see: Cook, Christopher R. "East Timor and the Power of International Commitments in the American Decision Making Process" Asian Pacific: Perspectives 9, no. 2 (2010). 